\title{
TEACHING READING BY USING GIST STRATEGY VIEWED FROM THE STUDENTS' COGNITIVE ASPECT ON THE EXTENSIVE LEVEL OF ENGLISH DEPARTMENT STUDENTS IKIP PGRI MADIUN \\ Nuri Ati Ningsih ${ }^{1)}$ Arri Kurniawan ${ }^{2)}$ \\ Fakultas Pendidikan Bahasa dan Seni, IKIP PGRI Madiun ${ }^{1)}$ email: nuri_basir@yahoo.com \\ Fakultas Pendidikan Bahasa dan Seni, IKIP PGRI Madiun²) email: arrikurniawan@yahoo.com
}

\begin{abstract}
This research aimed at (1) describing the implementation of GIST strategy in the process of teaching reading viewed from the cognitif aspect having by the students; (2) finding the positif aspects of the implementation of GIST strategy; (3) knowing the weaknesses of the implementation of GIST strategy in the process of teaching reading viewed from the cognitive aspect.

The method in this research was descriptive qualitative. In doing the research, there were some steps to be implemented to collect the data. They were observation, interview, and documentation. Then, analyzing data was done by reducing the data, presenting the data and drawing conclusion or verification.

The result of the research showed that (1) GIST has been implemented maximally by the lecture based on the characteristics of this teaching strategy. To dig up the students' cognitive aspects, the lecture provide the specific worksheet which represents the students' cognitive level for higher order thinking skill, (2) GIST creates the students' character in a good manner, such as; active, responsible and confident.They also learn how to work in a team; (3) Some weaknesses found in this research are; It needs a long time to create the instrument to support the implementation of GIST and Evaluation must be done by combining both cognitif level and the level of reading ability.
\end{abstract}

\section{Keyword: GIST, Teaching Reading, Extensive Level, Cognitive}

\section{Introduction}

Reading English text is a basic skill that should be possessed by students of English primary education students. Based on the level of literacy, on the extensive level, cognitive abilities students should have the highest level of order thinking or intellectual abilities. Grondlud (1997: 3233) describes that at this level the student must master the ability to understand, analyze, synthesize and evaluate something, and understand the text content of the English language properly.

Based on the results of the preobservation, this problem arises because the internal and external factors are owned by the student. Internal factor owned by the students is motivation. Weak motivation makes the students not able to optimize their cognitive abilities to read English-language text, and it is also supported by a low understanding of the indicators of reading literacy. 
This factor arose because the students do not have interest on reading text. While external factor faced by students is the environment. Environment in this case has a fairly broad meaning, including the family environment, and an environmental milieu in which students learn (campus). Conducive environment is not able to touch the obstacles faced by the students so it will not be able to resolve the problem as well.

From some of these factors, in this case, the researchers tried to provide a solution by providing learning strategies to motivate students to optimize the cognitive ability to understand the English language texts to identify some indicators of reading skills. This study aims to provide solutions to the problems experienced by English Department students of IKIP PGRI Madiun in understanding the content of English text. Through this study, researchers will, (1) describe the implementation of GIST in teaching reading English text on the extensive level in terms of the cognitive aspects of students, (2) find the positive impact arising from the implementation of GIST, (3) know the weaknesses arising from the implementation of the GIST strategy.

The results of this study are expected to be useful as a source of information about the level of benefit from the use of teaching strategies Reading GIST in the teaching process and as a feedback in the learning process of Reading I, II, III and IV in particular.

\section{Method of Research}

The method used in this study is descriptive qualitative research. It is because the researchers will portray the real conditions on the implementation of GIST strategy in teaching reading, the positive impact arising from the implementation of GIST, as well as weaknesses that arise from the implementation of GIST strategy.

Yatim Riyanto (2001: 23) argues that descriptive research is research that is geared to give symptoms, facts or events in a systematic and accurate information on the properties of populations or specific areas. Furthermore, in the opinion of Moleong inTanuwijaya (2000: 36) research procedures produce descriptive data in the form of words written or spoken of people and behaviors that can be observed. Based on this theory, it can be said that the method is descriptive qualitative research method that aims to describe the actual occurrence of the condition of the subject or object of research. Research data collection is done in several ways, namely:

\section{a. Observation}

Gulo (2004: 116) argues that the observation is a method of data collection in which researchers or collaborators record information as they witnessed during the study. In this case, the researchers recorded the events that 
occurred during the study. Observation used is non-participant observation, where the researcher is in charge of recording all events in the implementation of teaching strategies GIST by activating cognitive aspects of students in the lecture of reading. This is done to illustrate the true incidence of GIST implementation and optimization of cognitive aspects in an effort to improve the ability to read English text on extensive level, the positive impact arising from the implementation of teaching strategies GIST, as well as weaknesses that arise in the process.

\section{b. Interview}

Interview in this study is conducted independently or unstructuredly in order to obtain a detailed picture of the implementation of the strategy GIST in the process of teaching reading and how to activate the cognitive aspect to improve the ability to read the English subtitles on extensive level, then the positive impact arising from the implementation of teaching strategies GIST and activation of the cognitive aspects, as well as weaknesses that arise in the process.

\section{c. Documentation}

Creswell (2003:186-187) states that there are three documents, they are public documents (notes of meetings and newspapers), private documents (journals, diaries, and letters), and e-mail discussion. In this study, the type of documents used is private documents. Documents referred to this research is the type of documents held by the lecturer in the form of reading the syllabus, lesson plans, worksheets, results of student assignments, as well as documentation on the implementation of the strategy GIST. This document is used to analyze the positive impact arising from the implementation of teaching strategies GIST, as well as the weaknesses of the process.

\section{Results and Discussion}

Data processing or data analysis carried out on the data that has been collected through observation, interviews and documentation. The analysis was performed through several stages, namely; data reduction, data presentation and data verification.

\section{a. Data reduction}

At this stage the researchers sorts the data that have been collected adapted to the problem and research objectives.

\section{b. Presentation of Data}

The data have been sorted according to the indicators of the need for data in the study, and then presented in narrative form.

\section{c. Verification of Data}

At this stage, the researcher verifies the data or draw conclusions by finding relationships between data, then analyzed them in accordance 
with the problems and research

objectives.

GIST has been implemented by the lecturer of the course. It can be proved from the documents supporting the learning process of reading courses at level IV or on extensive level have been available before learning begins. These documents include the course syllabus, lesson plans for one semester and student worksheet used for one semester. Judging from the content of a lesson plan, especially on core activities, the lecturer has been designing the learning process by implementing teaching strategies GIST. Core learning steps have been prepared based on the characteristics of GIST are done in groups and through the following stages;

1.Identify some types of text which become the teaching material.

2.Make Group of students by members of the equity composition students who have high ability or above average as a group leader who will guide his friends, and then distribute the worksheet.

3.Demonstrate teaching strategies GIST by providing some questions related with $\mathrm{W}^{\prime} \mathrm{s}$ and $\mathrm{H}$ individually and in groups.

4.Tell students to write "GIST" in the form of a simple article consisting of 20 words
5.Discuss the contents of the text.

6.Read the text and compose a summary of each paragraph.

7.Read and compare the summary.

8. Evaluate the progress of reading comprehension.

Student worksheet is prepared by considering the characteristics of GIST and student cognitive aspects. Worksheet is prepared by providing a special text in English, then provide some stimulus of questions containing of the W's and $\mathrm{H}$ questions to help students predict the contents of the text. Cognitive aspects at the level of the students have also been accommodated in the worksheet compiled higher order thinking by providing a number of 20 boxes which will be filled with the vocabulary associated with the text reading and then be reassembled in a new sentence whose contents are still associated with the reading. The portion of activating the cognitive aspects of the students' worksheet is based on the description proposed by Burhan Nurgiayantoro that every level of education has a different portion, and each teacher must understand it, then implement it at the time in charge of teaching. After analyzing the research data, research results are translated in some detail below.

Based on the observation that has been done, the lecture or teaching process is generally divided into three stages. The first stage is pre activity or activities. At 
this stage of the activities carried lecturer was greeting, checking students, reviewing previous material and providing an introduction to the next matter. Furthermore, the second phase is a main activity. At this stage the main processes occur, namely how GIST strategy is implemented and how to activate the cognitive aspects of the student. Based on observations, the first step is done to instruct students to sit in groups. This group has been predetermined by the lecturer with the consideration of the spread/equalization students who have good ability in all groups. It is intended that the student can provide a stimulus or guidance to members of the group and as a leader of a member who has the ability underneath. The next step is to distribute the worksheets to all students. This worksheet is made by the lecturer of which the content is a lecturer activates students cognitive through some stimulus words and commands contained in the worksheet. After giving the students time to read and observe the worksheet, lecturer demonstrates teaching strategies to provide some stimulus GIST-related questions about the contents of the existing literature on the worksheet to make use of the W's and $\mathrm{H}$ questions to individuals and groups. Once there is an interaction between lecturer and students in an effort to understand the contents of the text, then lecturer gave instruction to write"GIST" reading or interpretation of the contents in the form of a simple article consisting of 20 words in groups. For a discussion of the work, each group presented their work. Comparison of the results of the work needs to be done to control the work as well as astep in the equation interpretations of the content of reading comprehension. The next step is to evaluate student progress in understanding the content of the English-language literature. At the end of the activity, lecturer and students reflected on the matter and learning steps that have been implemented, find common perceptionof the process and the materials and the last step is closing.

The classroom activities above were conducted in relation with the syllabus dan lesson plan created by the lecture before, and supported by the use of Reading worksheet compiled and used by lecturers as a guide during the lecture. The the result of interviews shows two different sides of effect conducting GIST in reading classroom activities. Fostering the students with providing "strenght" worksheet in certain period of time makes the students enthusiastic and bored. They are enthusiastic because of the different characteristics model of worksheet which encaurage the students not only to dig up their previous knowledge or prior knowledge deeply but also try to share the result among the groups. In contrast, they felt bored because the lecturer 
continuously applied GIST in the classroom every meeting.

\section{Conclusion}

Based on the analysis of research data collected, it can be concluded that;

a. GIST has been implemented by lecturer and performed by optimizing the cognitive aspects of student and it is actualized in the act of teaching in class and supporting documents such as student worksheet.

b. GIST implementation in the learning process has a positive impact on Reading including;

1) The output learning process looks real, i.e.students must be academically active during the process.

2) Ability to work in teams increases

3) The appearance of character "Asah Asih Asuh"

4) The emergence of responsible character and confidence.

c. Weaknesses that arise from the implementation of this GIST are;

1) Students feel that the implementation of sustainable GIST is very serious and it caused a bit of boredom.

2) Lecturer of reading courses requires considerable time and reference to the preparation of the implementation of GIST.

3) The cognitive aspect of students has already been explored through available several learning activities and worksheets but have not been measured optimally.

Based on the above conclusions, the results appearad few suggestions for the sustainable implementation of GIST as follows:

1) It needs a modification action on main activities learning process without changing the essence of the stages of learning that does not bring a sense of boredom for students.

2) It needs the specific evaluations of the cognitive aspects of the student so that the student possessed cognitive aspects that can be measured.

\section{REFERENCES}

Aebersold, Jo Ann \& Field, Marrie Lee. 1997. From Reader to Reading Teacher. Cambridge: Cambridge University Press.

Anderson, L. W. and David R. Krathwohl, D. R., et al (Eds..) (2001) A Taxonomy for Learning, Teaching, and Assessing: A Revision of Bloom's Taxonomy of Educational Objectives. Allyn \& Bacon. Boston, MA (Pearson Education Group 
Akmar Mohamad in http ://iteslj. org/ Techniques / Mohamad-Testing Reading.html

Brown, H. Douglas. 2000. Principles of Language Learning and Teaching. San Francisco: Addison Wesley Longman Inc.

Brown, H. Douglas. 2004. Language Assessment Principles and Classroom Practices. San Francisco: Addison Wesley Longman Inc.

Burhan, Nurgiyantoro, 2001, Penilaian dalam Pengajaran Bahasa dan Sastra, BPFE, Yogyakarta

Dahloan in http:// www. Associated content. Com/ shared /print.Shtml? content_type $=a r$

Deborah dalam www. Deborah healey.com/ reading/tataouine-summaries.pdf.

Elizabeth. 2004. Learning and Instruction. New York: Mc Graw-Hill, Inc.

Gronlund, N.E., \& Linn, R.L. (1990). Measurement and Evaluation in Teaching (6th ed.). New York: MacMillan.

Herrell, Andrienne L, (2008), Strategies for Teaching English Language Learners, Pearson Merrill Prentice Hall.

Lems, Kristin, et al. 2010. Teaching Reading to English Language Leraners, New York London: Guilford Press

Margono. 2000. Metodologi Penelitian Pendidikan. Jakarta: Rineka Cipta.

Morellion Judi, 2007. Collaborating Strategies for Teaching Reading Comprehension. Chicago; American Library Assosiation.

Nuttal, Christine. 2005. Teaching Reading Skills in Foreign Language, London: Heinemann Educational Book.

Nuri Ati Ningsih, Arri Kurniawan. 2013. Laporan Penelitian Dikti: Kajian Kemampuan Membaca Teks Bahasa
Inggris Mahasiswa Pendidikan Bahasa Inggris Pada Level Extensive IKIP PGRI Madiun. LPPM IKIP PGRI Madiun.

Rianto Adi.2005. Metodologi Penelitian Sosial dan Hukum. Jakarta: Granit.

Suharsimi Arikunto. 2002. Prosedur Penelitian. Jakarta: Rineka Cipta.

Sugiyono. 2007. Metode Penelitian Pendidikan: Pendekatan Kuantitatif, Kualitatif dan R\&D. Bandung : Alfabeta.

Sukardi.2006. Penelitian Kualitatif Naturalistik Dalam Pendidikan. Yogyakarta: Usaha Keluarga.

Sutopo H.B. 2002. Metodologi Penelitian Kualitatif. Surakarta: Sebelas maret University Press.

Yatim Riyanto .2001. Metodologi Penelitian Pendidikan. Surabaya. SIC 